\title{
Relationship between Corporate Governance and Risk Disclosure Practice from Malaysia Perspective
}

\section{Ag Kaifah Riyard Bin Kiflee ${ }^{1,2}$ and Mohd Noor Azli Bin Ali Khan ${ }^{3}$}

${ }^{1}$ Ph.D Scholar, Azman Hashim International Business School, Block T08, Universiti Teknologi, 81310, Johor Bahru, Johor, Malaysia

${ }^{2}$ Faculty of Business, Economics and Accountancy, Universiti Malaysia Sabah, 88400, Kota Kinabalu, Sabah, Malaysia

${ }^{3}$ Lecturer, Azman Hashim International Business School, Block T08, Universiti Teknologi, 81310, Johor Bahru, Johor, Malaysia

\section{Abstract}

Past accounting scandals (Transmile and Megan Media) and recent 2007/2008 global financial crisis have triggered the need for vibrant risk management and high quality of risk reporting through sound corporate governance. This study will measure risk management through the disclosure in the annual reports. It wishes to determine the

Corresponding Author: Ag Kaifah Riyard Bin Kiflee agkaifahriyard@gmail.com

Received: 5 August 2019 Accepted: 14 August 2019 Published: 18 August 2019

Publishing services provided by Knowledge E

(c) Ag Kaifah Riyard Bin Kiflee et al. This article is distributed under the terms of the

Commons Attribution License, which permits unrestricted use and redistribution provided that the original author and source are credited.

Selection and Peer-review under the responsibility of the FGIC2019 Conference Committee. presence of risk information within the annual report of non-financial companies in Malaysia. The objective of the study is to examine the relationship between corporate governance characteristics and risk disclosure practice. The corporate governance characteristics examined include board independence, the board size, board gender, auditor independence and auditor tenure. A total of 721 companies are expected to be analyzed based on the Bursa Malaysia list from 2008 to 2017. To determine the level of risk disclosure, this study will employ content analysis. Descriptive statistics and multiple regression will be used in this study to examine this relationship.

Keywords: risk disclosure, corporate governance, content analysis, multiple regression.

\section{Introduction}

In general, the annual report is seen as a platform to convey beneficial information to the stakeholder and potential investor as it comprises both monetary and non-monetary information (Azlan et al., 2009). However, due to internal and external factors, the business environment is progressively volatile. Studies conducted by Ernst and Young (2014) and Gjerald and Lyngstad, (2015) found that, the main contributors to the volatility and uncertainties experienced by today business environments are instead because of non-financial risk than financial risk. Abdullah et al. (2015) also stated that many of the unexpected downfalls happened in business environments is not due to financial issues but rather cause by non-financial factors. Natural disasters, political unrest, changes in 
government policy, a conflict among countries, inconsistent in global consumer demand was argued to influence the survivability of companies (Abdullah et al., 2015).

Despite the importance of disclosing non-monetary information, it was documented that management is giving less focus on the disclosure of non-monetary information and rather focus on disclosing monetary risk management information (Lajili \& Zéghal, 2005). The study also argued that by disclosing less non-financial risk information, it may misguide investors in making an informative decision. Cabedo \& Tirado (2004) argued that, investors or potential investor usually make their investment or disinvestment decision by assessing the return of an investment project and the risk level associated with the company itself. It was highlighted in a situation whereby the investors could not identify the risk factor of the company, a proper judgment into the risk associated could not be made and this may lead the investor to make uninform decision and cause severe loss to their investment (Abdullah et al., 2015).

Therefore, academicians and standard setters agreed that, to achieve high-quality corporate reporting, the management should not only emphasis on monetary information, but also the non-monetary risk information (ICAEW, 1999; CICA, 2009). Previous studies by (Solomon et al., 2000, 2011) agreed that the existence of extra risk management information will assist the investor in their portfolio investment decisions and indirectly reduce investor concern about the risk associated with companies (Orens \& Lybaert, 2007). Therefore, in order to improve their decision making, investors have requested the management to voluntarily disclose risk management information especially related to non-monetary information as in some countries, the disclosure practice is still optional (Financial Reporting Council (FRC), 2011). The past result also showed that companies still reluctant to increase their risk management information disclosure (Ali, 2013). One of the arguments by the companies is, some of the information may commercially sensitive and can not be freely disclosed to the public as it may put the company in disadvantages situations (FRC, 2011). However, debates whether the company should continue to undisclosed such information is still ongoing as some of the opinion are opposed the idea.

Following the accounting dilemma faced by the companies, one of the solutions is to impose greater disclosure, as this will improve transparency and assist the user to come with an informed decision about the company performance (Linsley \& Shrives, 2005). One of the significant and ongoing debates is whether the companies should enhance their transparency in their annual report as it was stated that shareholders and potential investors are receiving too little information about the company risk and the mitigation tools employed (Linsley \& Shrives, 2005). It also suggested that a company 
with good corporate governance tends to require their management to practice at the best interest of their shareholders by improving company risk mitigation tool and enhance understanding the company risk profile.

In response to upturn demand for better risk information disclosure has motivated past studies to further investigate factors who might affect the company risk disclosure (Saggar \& Singh, 2017). However, these studies arguably experience some limitations who may open for further research. Firstly, most of the prior literature in this field tend to study the effect of company-specific characteristics with company risk disclosure (Azlan et al., 2009; Baroma, 2014; Oliveira et al., 2011; Madrigal et al., 2015) and less between corporate governance and disclosure. Therefore, this study intends to investigate the effect of corporate governance characteristics with risk disclosure as the study between these two variables is scarce (Abraham \& Cox, 2007; Elshandidy et al., 2015; Oliveira, Rodrigues, et al., 2011) especially in emerging countries (Ntim et al., 2013; Saggar \& Singh, 2017; Said Mokhtar \& Mellett, 2013). The study on these variables will enrich the understanding of the effect of corporate governance on the risk disclosure by the company as it was argued that most of the corporate disclosure decision was decided by the board of the company (Beretta \& Bozzolan, 2004).

The main objective of this study is to explore the amount of risk disclosure report by Malaysian listed companies in the financial and non-financial section of their annual reports. To achieve the research aim, this study will perform content analysis on both sections of the annual report to investigate the availability of risk disclosure and types of risk being disclosed by Malaysian listed companies. Besides, this study also aims to test the effect of corporate governance characteristics (board independence, the board size, board gender, auditor independence and auditor tenure) on company disclosure and at the same time to measure the level of risk associated with the companies according to the disclosure made.

This paper will be organised as follows. The first section of the study will deal with the introduction and background of corporate governance in Malaysia, followed by theoretical development and reviews of the literature on the second part of the study. In the third section of this study, the researcher will discuss the applied methodology and followed by a summary of the final section of this study. 


\subsection{Corporate governance and risk reporting environment in Malaysia}

Famous accounting scandals such as Enron, Parmalat and WorldCom in the past have triggered the concern on the function of companies annual report as medium and source of information (Linsley \& Shrives, 2000). However, on the bright side, these famous accounting scandals have given positive feedback on the development of risk disclosure as most of the company tends to consider to disclose extra information to the public. In Malaysia, the finest example of the failure of corporate governance can be portrayed through Transmile case back in 2006. It was stated that creative accounting is the root which leads to this accounting scandal where the revenue and profit of the company are purposely manipulated for the best interest of the company (Norwani et al., 2011). Transmile was accused to purposely overstated their revenue for three years in a row (2004, 2005 and 2006) and at the same time, they also being accused to purposely fabricated the amount of their property, plant and equipment as there is less evidence to support all the transaction (Abdullah Zaimee, 2007). To conclude, Transmile scandal was caused by lower board monitoring on business and managerial activities, unreliable information in the annual report and the failure of the regulatory body to enforce sufficient regulation to listed companies in Malaysia (Norwani et al., 2011).

This crisis has raised awareness for the need better corporate governance systems in the company which sometimes only can be achieved through regulation implementation. Better corporate governance is crucial to secure shareholder interests and ensure the management objective is aligned with the interest of shareholders (Ghazali, 2004; Zadeh, 2015). Therefore, clear roles and responsibilities of the board of directors and managers are essential to assuring everyone is working at the best capacity of the company.

Akhtaruddin et al. (2009) argued that corporate governance could become a tool for internal control to reduce agency problems. It was stated, under comprehensive governance monitoring, the manager tendency to withhold information may be reduced which will lessen the manager opportunistic behavior and improve the information asymmetry which results in enhancing corporate disclosure (Ho \& Shun Wong, 2001).

In Malaysia, the Malaysian Code on Corporate Governance (MCCG) was first introduced in March 2000 and had undergone through a series of the amendment to fulfill the need of current corporate governance issues (Akhtaruddin et al., 2009; MCCG, 2017). Also, Bursa Malaysia, who formerly known as Kuala Lumpur Stock Exchange 
(KLSE), in January 2001, has instigated their own version of the listing rule code for listed companies in Malaysia. These codes rather focused on the need for transparency, accountability, internal control, board proportional, and directors' reimbursement among listed companies in Malaysia. Akhtaruddin et al. (2009) also stated that, corporate governance indeed is an important mechanism used by the management to achieve corporate objectives while the disclosure is argued acting as a tool used by management to channel company performance to the public.

Besides, it was suggested that Companies Act of 1965 and Malaysian Accounting Standard Board (MASB) are the main standards who embody the corporate disclosure and reporting style of listed companies in Malaysia (Akhtaruddin et al., 2009). The Ninth Schedule of the companies Act 1965 mandated that all listed companies under Bursa Malaysia to prepare and submit all the related documents upon the annual general meeting. This is to ensure that all related information including the respective value of certain items is clearly included in the annual report align with the requirement of the standard. Companies Act 1965 also stated that the preparation of the annual report must be solely conducted by company directors. Besides, before the annual report being presented to the public, it is crucial for the annual report to be audited by qualified auditors to align with the requirement of the Act. Bursa Malaysia also adheres all the listed companies in Malaysia to comply with their listing rules of disclosure and reporting (Akhtaruddin et al., 2009).

To enhance the quality of reporting and disclosure among listed companies in Malaysia, the government of Malaysia has implemented several measures such as the introduction of the Financial Reporting Act back in 1997. Under this Act, MASB was promulgated with the main objective to govern and issue accounting standard related to disclosure. Before the MASB establishment, all the accounting standards in Malaysia were governed by two accounting professional bodies, namely the Malaysian Institute of Accountant (MIA) and the Malaysian Institute of Certified Public Accountants (MICPA). MIA is responsible to govern the accounting profession in Malaysia while MICPA is private accounting body who recognizes accounting profession professionally to all accountants in Malaysia (Susela, 1999). Nowadays, MASB is solely responsible to establish and present accounting standard according to the need and requirement of international standard. To ensure MASB working effectively and efficiently, Financial Reporting Foundation (FRF) was introduced under the capacity of the Financial Reporting Act 1997 to assist MASB in producing complete and functional standards for listed companies in Malaysia (Akhtaruddin et al., 2009). One of the FRF objectives is to oversee MASB performance and also act as a reviewer for the accounting standard 
govern and issued by MASB. However, FRF has no privilege to develop and issue accounting standard.

Prior literature has suggested that disclosure from the company is the mean way to create assurance among present and potential investor (Azlan et al., 2009). It also noted that company disclosure is associated with corporate governance whereby a company with sturdy governance have a higher tendency to disclose more information to attract investors. It is to note that previous studies have examined the relationship between governance and company value, however, only a few of the study to focus on the relationship between governance variables and company disclosure (Akhtaruddin et al., 2009; Chen \& Jaggi, 2000). Therefore, this study will focus on examining the relationship between corporate governance mechanism and its effect on company disclosure.

\subsection{Theoretical development}

\subsubsection{Agency theory}

Throughout the years, various researchers have continued to further refine the meaning of agency theory to explain the current business environments. Among conducted studies, a study conducted by Fama \& Jensen (1983) and Jensen \& Meckling (1976) might probably offer the best explanation of the theory. Mallin (2007) suggested that agency theory is a relationship between the principal (markets) and agents (management) whereby the principal delegates the work to agents with expectations that the agents will work for the interest of principals. This is aligning with a study conducted by An et al. (2011) who also agreed that agency theory relationship could be portrayed through the relationship of company shareholders who acting as principals and management who acting as an agent. A study conducted by Jensen \& Meckling (1976) revealed that the agency cost tends to rise due to a separate entity between shareholders and management. In addition, it also suggested that, the probability of conflict of interest to occur between agents is higher as there is a higher possibility of separation between ownership and management of the company.

It also explained that in a situation whereby the monitoring mechanism of shareholders and creditor is missing, the manager has the higher tendency to act in their own best interest by withholding or manipulating the relevant information by purposely disclosing misleading information to the market (Latham and Jacobs, 2000). Moreover, agency cost also occurred due to information asymmetry enjoy by the manager who capable to access extra information than shareholders (Jensen \& Meckling, 1976). Therefore, to 
minimize agency cost between shareholders and managers, an optimal contract may be proposed as a means of aligning the objective between the two parties (Healy \& Palepu, 2001). It also suggested, voluntary disclosure is another meaningful way to improve agency cost (Barako et al., 2006) as it tells the market that the company is performing well (Watson et al., 2002).

The finding of past studies has shown mix result of disclosure due to different determinants employed in the studies which this could be explained through the agency theory relationship (Azlan et al., 2009; Craven \& Marston, 1999; Rajab \& Schachler, 2009). It was argued that agency theory could assist an investor in planning proper mitigation tools as the theory is able to explain the relationship between the uncertainty and disclosure practice of the company (Zadeh, 2015). In a surveyed study conducted by Solomon et al. (2000) documented that one-third of the institutional investors agreed that the return on their investment is higher when the company is practicing higher disclosure. Moreover, it also stated that to improve agency cost, the company may employ effective corporate governance as monitoring mechanisms to overview managerial self-interest behavior. Therefore, by mean of improving risk disclosure practice, agency cost should be reduced by improving the relationship between shareholders and management.

\subsubsection{Signalling theory}

The phrase 'signal' was first introduced by Robert Jarvis in 1970 and further refined by Spence (1973) in order to explain market reactions. It was discussed that the company with positive performance has a higher tendency to enclose their future strategy to the market by disclosing their current company activities (Eccles et al. 2001). Spence (2002) defined signal as a form of information conveys by agents to the market who usually encloses the information of the company. In addition, the signal also is formed of multiple understanding signs which usually conveys by the agents to the principals (Aryani, 2016). It was found that, in higher information asymmetry market, it is typical to observe manager signaling activities to the market (Morris, 1987). The theory posits that due to the responsibility of the manager to disclose beneficial information to the market, the managers uniform to disclose extra risk information in the presented annual report (Haniffa \& Cooke, 2002). Therefore, to have a high quality of the annual report, managers are then encouraged to disclose credible information to the market (Hughes, 1986).

Signal theory postulated that through disclosure practice of information by the company, the company able to signal its positive performance to the market (Zadeh, 2015). 
Zadeh (2015) also stated that information disclosed by the company is a mean way of signaling the market on the company performance especially in today volatile business environment. In addition, it also documented that the share price of the company could increase due to information disclosure by the company as it directly associated with the capital market (Zadeh, 2015). In addition, the study also found that management remuneration is also reflected through disclosure practice by the company as higher disclosure of information indicated the positive performance of the company (Singhvi \& Desai, 1971). Moreover, it also noted that a profitable company has greater motivation to signal to the market as a meaning of acquiring market share (Wallace et al. 1994; Wallace \& Naser, 1995).

However, in a real business situation, the managers have the option either to disclose or withhold information (Ali, 2013). In some situation, the manager may be reluctant or purposely send wrong information to the market which is totally opposite to the actual situation (Aryani, 2016). Estrada (2011) argued that vague signal can be categorized as non-verifiable statements whereby this kind of information can be existing in the form of neutral attributes (neither positive nor negative or good or bad) within the annual report. Aryani (2016) also revealed that the company may purpose to disclose vague information to the market to mask their low performance. Besides, past studies also argued that it is challenging to attain the manager true attention based on the information discloses in the annual report. Therefore, this study will employ signal theory as a meaningful way to explain the nature of risk information disclosed by Malaysian listed companies in Malaysia.

\section{Hypothesis Development}

The main objective of this study is to examine the effect of corporate governance on risk disclosure practice among Malaysian listed companies. This study identified five corporate governance determinants who potentially influenced risk disclosure practice. Therefore, the hypothesis developments in relation to independent variables are stated as follows:

\subsection{Board independence}

The presence of independent directors on the board arguably improved the agency problem faced by the companies as it will act as the connecting party who fills the information gap between the managers and the management. It was argued that the 
role of independent directors and the structure of the board play an essential role in improving owner-manager conflicts (Weisbach \& Hermalin, 2000). However, the effectiveness of independent directors to encourage disclosure practice could only be achieved if they are able to execute their role properly (Fama \& Jensen, 1983).

A study conducted by Akhtaruddin et al. (2009) suggested that the composition of the board is playing a vital role in determining the effectiveness of corporate governance of the company as a mean of reducing agency conflict. While, Elshandidy et al. (2013) also documented that company voluntary and mandatory disclosure is heavily influenced through the proportion of independent director. A study conducted in the UK found that, the presence of independent directors on the board has enhanced the disclosure motivation and at the same time reduce the agency cost (Abraham \& Cox, 2007). In addition, managerial opportunistic behavior is argued could be reduced through effective monitoring from independent directors (Florackis \& Ozkan, 2008; Kiel \& Nicholson, 2003; Williams et al., 2006). While, it also argued the company transparency could be improved with the presence of a higher degree of independent directors (Sheila et al., 2011).

Despite the positive impact of independent directors to company disclosure practice, a study conducted by Gul \& Leung (2004) documented that a higher proportion of independent director also contributed to lower disclosure practice by the company due to complex board hierarchy. It was argued that, this is caused by dissimilar objective sharing between independent director and manager who cause the decision making to become complicated (Demb \& Neubauer, 1992). In addition, it also might contribute by other issues, such as the failure of the board to monitor the manager efficiently who finally contributed to increasing information asymmetry (Lin, Pope, \& Young, 2003). It also noted that, in the presence of higher directorship ownership, the power of an independent director to influence company disclosure practice may lower (Leung \& Horwitz, 2004).

It is documented that with the involvement of a higher percentage of independent directors on the board, the shareholder could anticipate higher voluntary disclosure practice by the companies (Leftwich, Watts and Zimmerman, 1981). It is also expected that the quality of disclosure will enhance the involvement of external directors on the board (Akhtaruddin et al., 2009; Chen \& Jaggi, 2000). It was suggested that the presence of external auditor and director plays a vital role in corporate governance as it will encourage the company to disclose sufficient and quality information to the market. A company may experience a higher level of disclosure in the presence of an 
extra external director. Therefore, following the arguments, the following hypothesis is formulated:

$\mathrm{H}_{1}$ : There is a positive relationship between a higher proportion of independent director on board and risk disclosure practice in Malaysian listed companies.

\subsection{Board size}

It was revealed that the company level of disclosure is a strategic decision made by the board of the company. As the higher level of management in the company, the board of directors is responsible to establish policies and effective strategies for the best interest of the company which later was executed by the managers (Akhtaruddin et al., 2009). It was documented that, a higher number of directors present on the board would improve the information asymmetry (Chen \& Jaggi, 2000). It was stated companies with large board size are having more agent to oversee managerial behavior to improve internal control issues and promote disclosure. It also realized that directors in larger board size usually present with a different background of expertise which makes it beneficial for the company (Sheila et al., 2011). However, it is to note that a larger board size does not necessarily come with positive impact. For example, companies in the UK prefer to have a smaller board rather due to a larger board complex hierarchical which lead to diminishing communication between the two parties (Guest, 2008). Meanwhile, Zaluki and Wan Hussin (2009) revealed that the size of the board was not affected the quality of financial disclosure among Malaysian public companies. In addition, it also mentioned that a complex board structure and large board tend to associate with ineffective communication and coordination who lead to poor decision making (Akhtaruddin et al., 2009).

Agency theory argued corporate governance mechanisms play a vital role in the effort to improve the agency conflict where this can be implemented through extra monitoring from directors to the management of the company (Ntim et al., 2013). It was suggested the board must consist of at least 7-8 members for it works effectively (Florackis \& Ozkan, 2008; Jensen, 1993). Besides, it was documented that a larger board is rather experienced in handling various situations and capable to improve transparency due to the various background of their directors (Nuhu \& Hussani, 2017; Xie et al., 2003). Therefore, this study expected that:

$\mathrm{H}_{2}$ : There is a negative relationship between larger board size and risk disclosure practice in Malaysian listed companies. 


\subsection{Board gender}

A study conducted by Al-Shaer \& Zaman (2016) in sustainability disclosure documented that multi-gender board is affecting the quality of the sustainability report. It was argued that female director, either independent or non-independent, due to their respective personality, communications skills and expertise tend to demand transparent sustainability report (Al-Shaer \& Zaman, 2016; Liao et al., 2015). In addition, problem-solving skill among multi-gender board is rather efficient due to the richness of directors' experience. Despite the possibility of a positive impact of multi-gender board and reporting quality, it was argued that, the size of the board is playing an important role in determining the company corporate disclosure practice (Michelon \& Parbonetti, 2012).

It has been posited that the presence of multi-gender director on board plays an essential role in influencing company transparency. One of the positive impacts of multi-gender board especially in a large company is, they will encourage for quality disclosure while in small companies, this type of board will encourage the collection of internal information among users (Gul et al., 2011). It is also documented that, the presence of female directors on board will enhance the quality of a board meeting which will affect the disclosure decision by the company (AI-Shaer \& Zaman, 2016). Besides, it also revealed that an issue which not discussed among all-male directors were openly discussed in the multi-gender board (Clarke, 2005; Huse \& Solberg, 2006). Joy (2008) also studied that, in the multi-gender board, the communication between boards and users is rather effective, allowing for greater information exchange between the two parties.

However, despite the advantages of multi-gender board, it was studied that multigender board also contributed to increasing conflict among directors due to their different roles and backgrounds (Boone \& Hendriks, 2009; Mannix \& Neale, 2005). This is aligned with the study conducted by Ray (2005) who found that one of the factors who contributed to conflict among multi-gender directors is due to varied ideology and background. The same study also found that, there is a higher possibility for the multigender board to choose safe harbor decision to reduce conflict among them. Thus, this study posited that, the multi-gender board will be likely to contribute to higher disclosure by the company.

$\mathrm{H}_{3}$ : There is a positive relationship between multi-gender board and risk disclosure practice in Malaysian listed companies. 


\subsection{Auditor independence}

To ensure a credible report is issued, a qualified opinion present by the auditor must be free from internal and external intimidation. This as a mean of ensuring the annual report presentation to the public is truthful and capable in explaining the situation associated by the company to find an effective solution for the risk associated (Barizah Abu Bakar et al., 2005). It was found that most of the auditor independence studies were conducted in the financial restatement and financial reporting quality and the result found that the independent auditor does lower the financial restatement which improves the quality of information (Wahab et al., 2014). Tepalagul \& Lin (2015) agreed that Big 4 auditors are generally more independent than non-Big 4 auditors as they underwent professional training which makes them more adept with variety company situation (Carcello \& Nagy, 2004). It also argued that Big 4 auditors have a higher tendency to influence the company disclosure due to their degree of independence, experience and skill degree of influence on company disclosure due to their degree of independence, experience and skill (Krishnan, 2003).

It was found that the auditor 'independence' is closely related to the audit fee imposed by the audit firms (Stanley \& Todd DeZoort, 2007). Previous studies found that, in an effort to attain a new client, the auditor may purposely engage in low balling tactics whereby they charge the audit service fee rather below the market price (Sankaraguruswamy \& Whisenant, 2003). It is expected that, by engaging in such tactics, auditor independence may be impaired which later will affect the company disclosure practice. It was noted that Big 4 audit firms usually imposed higher audit fees than nonBig 4 audit firms due to their facilities and auditors background (Tang et al., 2016). It was argued that the differences employed in term of quality between auditors in Big 4 audit firms and non-Big 4 audit firms may determine the quality of disclosure. Therefore, it was posited that auditor independence may affect the company risk disclosure practice among listed companies in Malaysia.

$\mathrm{H}_{4}$ : There is a positive relationship between auditor independence the level of risk disclosure practice in Malaysian listed companies.

\subsection{Auditor tenure}

Based on the case study in tea factories in Kenya, it was revealed that duration of auditor stay is significantly influenced company disclosure practice (Chepkorir, 2013). It was found that long auditor tenure will lower the probability for the auditor independence 
to be impaired (Chepkorir, 2013). A study conducted by Barizah Abu Bakar et al. (2005) argued that longer auditor tenure is rather familiar with the risk associated with the company which later will assist in producing a comprehensive annual report to aid market in making an informative decision. In contrast, it is noted that short auditor tenure has a higher probability to impair their own independence which affects the audit quality and quality of information embedded (Chepkorir, 2013). However, it was found that unsystematic audit procedure often incurred by long audit tenure which this is arguable will affect the company risk report (Mautz \& Sharaf, 1961). While Carcello \& Nagy, (2004) and Ghosh \& Moon (2005) in another context found that financial reporting fraudulent is positively caused by short tenure auditor.

Based on the AAERS (Accounting and Auditing Enforcement Release) report issues by SEC, it was found that, in the first three years of auditors tenure, the possibility of financial fraud in the companies is higher which indicated the importance of the period of auditor stay (Carcello \& Nagy, 2004). A similar study also did not find any evidence who stated that longer auditor period may contribute to company misconduct. However, Stanley \& Todd DeZoort (2007) studied that throughout the period of auditors stay, the quality of financial report and audit practices will increase. Moreover, it also suggested that company market performance such as stock rankings and return may be influenced through the relationship between auditor tenure and company misconduct. Therefore, this study expected that longer auditor period stay will influence the company disclosure.

$\mathrm{H}_{5}$ : There is a positive relationship between longer auditor tenure and risk disclosure practice in Malaysian listed companies.

\section{Methodology}

In particular, this study intends to choose the quantitative method as the main approach in the effort to explain the disclosure trend and the relationship between corporate governance and risk disclosure practice among listed companies in Malaysia. To assess the level of risk disclosure practice among listed companies in Malaysia, this study will employ content analysis. Krippendorff (2004) stated that content analysis is a method of answering the research question and objectives formulated by the study through replicable and acceptable deduction from the information extract. Mohammadi (2017) and Smith \& Taffler (2000) highlighted that content analysis can be segregated into two, 'form oriented' and 'meaning oriented'. However, this study will employ 'meaning oriented' whereby potential themes are identified through the set of the keyword in 
sentences (Bamber \& McMeeking, 2010). In addition, this approach also includes the analysis of negative and positive phrases identifies from the sentences. This method of sentence analysis is arguably aligned with the study conducted by (Azlan et al., 2009; Linsley et al., 2006; Farahnaz Orojali Zadeh et al., 2016) as it was agreed that the extract data is rather precise, reliable and competence (Milne \& Adler, 1999).

The samples intend to be investigated in this study including all the non-financial companies listed in Bursa Malaysia from 2008 to 2017 (10 years). However, this study will exclude companies who listed in the financial, open and close fund and insurance industries. It was stated that financial industries have their own set of rule and regulation who govern and issued by Central Bank of Malaysia which abide with institutional Bank and finance Act 1989 (Rahmat \& Mohd Iskandar, 2004; Abd Aziz, Mohd Iskandar \& Mohd Saleh, 2006). While, for financial and insurance companies, it was stated this two type of industries are having their format of the annual report and set of users (Mohd Isa, 2006). There are about 940 companies listed in Bursa Malaysia in 2017. However, this study only analyses the company with a complete set of the annual report which aligns with the study conducted by (Zadeh et al., 2016). This study allowed the researcher to have a clear picture of the level of risk disclosure by listed companies in Malaysia. Therefore, samples of 721 companies listed in Bursa Malaysia are expected to be analyzed (after excluding financial institutions and insurance companies) in order to determine the level of risk disclosure among listed companies in Malaysia.

\subsection{Measuring the independent variables}

Board independence (BID): Board independence is the magnitude of the independent directors on the board (Yunos, 2011). For the purpose of this study, the proportion of independent directors will be manually calculated and collected from the respective annual reports. This method is consistent with a study conducted by Macchioni, Allini and Rossi (2014), and Allini, Manes Rossi and Hussainey (2016).

Board size (BSze): Board size can be defined as the total number of directors who sits on the board (Ronnie Lo, 2010). Studies conducted by Ahmed and Duellman (2007), Krishnan and Visvanathan (2008) and Lam and Lee (2008) also employed a similar method in computing the board size, whereby the data were manually collected from annual reports.

Board Gender (BGdr): Board gender diversity arguably capable to improve the company disclosure quality and enhance the company performance by enclosing rich information to users (Boone \& Hendriks, 2009; Ray, 2005). Therefore, to measure 
board gender diversity, this study will employ two alternatives: (1) the number of female directors on the board and (2) the number of independent female directors on the board. This is in alignment with studies conducted by Gul, Srinidhi and Ng, (2011) and Al-Shaer and Zaman (2016) that employed the same method in measuring board gender.

Auditor Independence (AUIND): To measure auditors' independence, this study will employ the audit fee as studied by Stanley and Todd DeZoort (2007) and Tang, Chen and Lin (2016) to determine the effect of auditor independence to risk disclosure practices. Therefore, auditor independence will be measured by dividing the audit fees with total assets (Tang et al., 2016).

Audit tenure (AUTNR): Audit firm-client relationship is measured through the number of years the audit firms have been working with clients in performing the audit task. This method is aligned with the study conducted by Ball et al. (2015).

\section{Conclusions}

This study intends to investigate the determinants of corporate governance mechanisms who may affect the company risk disclosure practice. It is arguably stated that most of earlier disclosures studies tend to disclose qualitative information and rather focus on the past news. This has motivated the current study to further investigate the level of risk disclosure practice by Malaysian listed companies and extend the current literature by determining the determinants who may affect risk disclosure practice by focusing the narrative section of the annual report in an effort of explaining the disclosure phenomena.

It was argued that most of the company tend to disclosure their risk information on the non-financial section of the annual report such as chairman statement. However, in some study, it was found that some of the companies may conduct extra effort by providing separate sections such as Management, Discussion, and Analysis and Operation Review to disclose risk information. The outcome of this study is expected to be beneficial to researchers who especially interested in corporate disclosure area, the professional bodies and standard setters to keep updating on the factors who might affect risk disclosure in Malaysia. Risk is arguably will continue to exist in a volatile business environment and an effective mitigation tool may come handy to improve transparency and reduce information asymmetry. 


\section{Acknowledgement}

The authors would like to express our appreciation to the committee and the anonymous reviewers for their constructive comments and suggestion. We also appreciated all the comments received from participants during the $2^{\text {nd }} \mathrm{FGIC}$ conference held in Yayasan Pahang, 19-20 August 2019.

\section{References}

[1] Abd Aziz, N.H., Mohd Iskandar, T., \& Mohd Saleh, N. (2006). Pengurusan Perolehan: Peranan Kualiti Audit Dan Urus Tadbir Korporat. International Journal of Management Studies, 13(Special Issue), 163-188.

[2] Abdullah Zaimee. (2007). Mini Enrons shaking up Malaysia“s corporate governance? Accountant Today, Vol. 20 (7), 21-23.

[3] Abdullah, M., Abdul Shukor, Z., Mohamed, Z. M., \& Ahmad, A. (2015). Risk management disclosure: A study on the effect of voluntary risk management disclosure towards firms value. Journal of Applied Accounting Research, 16(3), 400432. https://doi.org/10.1108/JAAR-10-2014-0106

[4] Abraham, S., \& Cox, P. (2007). Analysing the determinants of narrative risk information in UK FTSE 100 annual reports. British Accounting Review, 39(3), 227-248. https: //doi.org/10.1016/j.bar.2007.06.002

[5] Akhtaruddin, M., Hossain, M. A., Hossain, M., \& Yao, L. (2009). Corporate Governance and Voluntary Disclosure in Corporate Annual Reports of Malaysian Listed Firms, 7(1), 1-20. https://doi.org/10.1016/0042-6822(73)90118-9

[6] Ali, M. M. (2013). Corporate Risk Disclosure, Upper Management Characteristics, Ownership Structure And Firm Value: Malaysian Evidence. Degree Of Doctor Of Philosophy.

[7] Al-Shaer, H., \& Zaman, M. (2016). Board gender diversity and sustainability reporting quality. Journal of Contemporary Accounting \& Economics, 12(3), 210-222. https: //doi.org/10.1016/j.jcae.2016.09.001 and Disclosure, CICA, Ontario.

[8] Aryani, D. W. I. N. (2016). The Determinants and Value Relevance of Risk Disclosure in the Indonesian Banking Sector, (February). Degree Of Doctor Of Philosophy.

[9] Azlan, A., Rosli, A. M., \& Hassan, C. H. M. (2009). Risk reporting: An exploratory study on risk management disclosure in Malaysian annual reports. Managerial Auditing Journal, 24(1), 39-57. https://doi.org/10.1108/02686900910919893 
[10] Bamber, M., \& McMeeking, K. (2010). An examination of voluntary financial instruments disclosures in excess of mandatory requirements by UK FTSE 100 non-financial firms. Journal of Applied Accounting Research, 11(2), 133-153. https: //doi.org/10.1108/09675421011069504

[11] Barako, D. G., Hancock, P., \& Izan, H. Y. (2006). Factors influencing voluntary corporate disclosure by Kenyan companies. Corporate Governance: An International Review, 14(2), 107-125. https://doi.org/10.1111/j.1467-8683.2006.00491.x

[12] Barizah Abu Bakar, N., Rahim Abdul Rahman, A., \& Majdi Abdul Rashid, H. (2005). Factors influencing auditor independence: Malaysian loan officers' perceptions. Managerial Auditing Journal, 20(8), 804-822. https://doi.org/10.1108/ 02686900510619665

[13] Baroma, B. (2014). The association between the level of risk disclosure and corporation characteristics in the annual reports of Egyptian companies. American Journal of Business, Economics and Management.

[14] Beretta, S., \& Bozzolan, S. (2004). A framework for the analysis of firm risk communication. International Journal of Accounting, 39(3), 265-288. https://doi. org/10.1016/j.intacc.2004.06.006

[15] Boone, C., \& Hendriks, W. (2009). Top Management Team Diversity and Firm Performance: Moderators of Functional-Background and Locus-of-Control Diversity. Management Science, 55(2), 165-180. https://doi.org/10.1287/mnsc.1080.0899

[16] Cabedo, J. D., \& Tirado, J. M. (2004). The disclosure of risk in financial statements. Accounting Forum, 28(2), 181-200. https://doi.org/10.1016/j.accfor.2003. 10.002 Canadian Institute of Chartered Accountants (CICA) (2009), MD\&A: Guidance on Preparation.

[17] Carcello, J. V., \& Nagy, A. L. (2004). Client size, auditor specialization and fraudulent financial reporting. Managerial Auditing Journal, 19(5), 651-668. https://doi.org/10. 1108/02686900410537775

[18] Chen, C. J. P., \& Jaggi, B. (2000). Association between independent nonexecutive directors, family control and financial disclosures in Hong Kong. Journal of Accounting and Public Policy, 19(4-5), 285-310. https://doi.org/10.1016/S02784254(00)00015-6

[19] Chepkorir, C. (2013). Factors Influencing Auditor's Independence and Accountability: A Case Study of KTDA Affiliated Tea Factories in Bomet and Kericho County, Kenya. Thesis, 1-46. https://doi.org/10.1017/CBO9781107415324.004

[20] Clarke, C.J., (2005). The XX factor in the boardroom: why women make better directors. Directors Monthly, (August), 12-14. 
[21] Craven, B. M., \& Marston, C. L. (1999). Financial reporting on the Internet by leading UK companies. European Accounting Review, 8(2), 321-333. https://doi.org/10.1080/ 096381899336069

[22] Demb, A., \& Neubauer, F. F. (1992). The corporate board: Confronting the paradoxes. Long range planning, 25(3), 9-20.

[23] Eccles, R. G., Herz, R. H., \& Keegan, E. (2001). Mary/Phillips, David MH (2001): The value reporting revolution: moving beyond the earnings game. New York.

[24] Elshandidy, T., Fraser, I., \& Hussainey, K. (2013). Aggregated, voluntary, and mandatory risk disclosure incentives: Evidence from UK FTSE all-share companies. International Review of Financial Analysis, 30, 320-333. https://doi.org/10.1016/j. irfa.2013.07.010

[25] Elshandidy, T., Fraser, I., \& Hussainey, K. (2015). What drives mandatory and voluntary risk reporting variations across Germany, UK and US? British Accounting Review, 47(4), 376-394. https://doi.org/10.1016/j.bar.2014.06.001

[26] Ernst and Young (EY) (2014), “Top 10 risks in telecommunications 2014”, available at: www.ey.com/ (accessed January 2015).

[27] Estrada, F. (2010). Thomas S. Schelling: game theory and indirect communication.

[28] Fama, E. F., \& Jensen, M. C. (1983). Separation of Ownership and Control Separation of Ownership and Control. Journal of Law and Economics, 26(2), 301-325. https: //doi.org/10.1086/467037

[29] Financial Reporting Council (FRC) (2011), Boards and risk: a summary of discussions with firms, investors and advisors, FRC, London, September.

[30] Florackis, C., \& Ozkan, A. (2008). Agency costs and corporate governance mechanisms: Evidence for UK firms. International Journal of Managerial Finance, 44(1904), 37-59. https://doi.org/10.1108/17439130810837375

[31] Ghazali, nazli A. M. (2004). Exploring Theoretical Explanations of Voluntary Disclosure By Quantitative and Qualitative Investigation: Evidence From Malaysia, (September).

[32] Ghosh, A., \& Moon, D. (2005). Auditor tenure and perceptions of audit quality. Accounting Review, 80(2), 585-612. https://doi.org/10.2308/accr.2005.80.2.585

[33] Gjerald, O., \& Lyngstad, H. (2015). Service risk perceptions and risk management strategies in business-to-business tourism partnerships. Tourism Management Perspectives. https://doi.org/10.1016/j.tmp.2014.10.002

[34] Guest, P. M. (2008). The determinants of board size and composition: Evidence from the UK. Journal of Corporate Finance, 14(1), 51-72. https://doi.org/10.1016/j.jcorpfin. 2008.01.002 
[35] Gul, F. A., \& Leung, S. (2004). Board leadership, outside directors' expertise and voluntary corporate disclosures. Journal of Accounting and Public Policy, 23(5), 351-379. https://doi.org/10.1016/j.jaccpubpol.2004.07.001.

[36] Gul, F. A., Srinidhi, B., \& Ng, A. C. (2011). Does board gender diversity improve the informativeness of stock prices? Journal of Accounting and Economics, 51(3), 314338. https://doi.org/10.1016/j.jacceco.2011.01.005

[37] Haniffa, R. M., \& Cooke, T. E. (2002). Culture, corporate governance and disclosure in Malaysian corporations. Abacus, 38(3), 317-349. https://doi.org/10.1111/1467-6281. 00112

[38] Healy, P., \& Palepu, K. (2001). Information asymmetry, corporate disclosure, and the capital markets: A review of the empirical disclostire literature. Journal of Accounting and Economics, 31, 405-440. https://doi.org/10.1016/S0165-4101(01)00018-0

[39] Ho, S. S. M., \& Shun Wong, K. (2001). A study of the relationship between corporate governance structures and the extent of voluntary disclosure. Journal of International Accounting, Auditing and Taxation, 10(2), 139-156. https://doi.org/ 10.1016/S1061-9518(01)00041-6

[40] Hughes, P. J. (1986). Signalling by direct disclosure under asymmetric information. Journal of Accounting and Economics, 8(2), 119-142. https://doi.org/10.1016/01654101(86)90014-5

[41] Huse, M. \& Solberg, A. (2006). How Scandinavian women make and can make contributions on corporate boards. Women in Management Review, 21, 113-130.

[42] Institute of Chartered Accountants in England and Wales (ICAEW) (1999a), No Surprises: The investors and advisors", FRC, London, September.

[43] Jensen, M. C. (1993). the Modern Industrial Revolution, Exit, and the Failure of Internal Control Systems the Failure of Internal Control Systems. Journal of Finance, 48(3), 831-880. https://doi.org/10.1111/j.1540-6261.1993.tb04022.x

[44] Jensen, M., \& Meckling, W. (1976). Theory of the firm: Managerial behavior, agency costs and ownership structure. Journal of Financial Economics, 3, 305-360. https: //doi.org/10.1016/0304-405X(76)90026-X

[45] Joy, L. (2008). Women board directors in the United States: An eleven-year retrospective. Women on corporate boards of directors: International research and practice, 15-23.

[46] Kiel, G. C., \& Nicholson, G. J. (2003). Board Composition and Corporate Performance: how the Australian experience informs contrasting theories of corporate governance. Corporate Governance, 11(3), 189-205. https://doi.org/10.1111/1467-8683.00318 
[47] Krippendorff, K. (2004). Content Analysis An Introduction to Its Methodology. an introduction to its methodology. Retrieved from http://books.google.com/books?hl=en\&lr=\&id=q657o3M3C8cC\&oi=fnd\&pg= PA3\&dq=content+analysis+and+introduction+to+its\&ots=bK8kw1JfBZ\&sig= oZChLqLZbPpLe_MUNDIdOt4AvS8\{\%\}5Cnpapers2://publication/uuid/91EOB6B25CD7-491A-AF76-FADCBF51BA9B

[48] Krishnan, G. V. (2003). Does big 6 auditor industry expertise constrain earnings management? Accounting Horizons. https://doi.org/10.2308/acch.2003.17.s-1.1

[49] Lajili, K., \& Zéghal, D. (2005). aAcontent analysis of risk management disclosures in canadian annual reports. Canadian Journal of Administrative Sciences / Revue Canadienne Des Sciences de L\&apos;Administration, 22, 125-142. https://doi.org/ 10.1111/j.1936-4490.2005.tb00714.x

[50] Latham, C. K., \& Jacobs, F. A. (2000). Monitoring and incentive factors influencing misleading disclosures. Journal of Managerial Issues, 12(2), 169-187.

[51] Leftwich, R., Watts, R., and Zimmerman, J. (1981). Voluntary corporate disclosure: the case of interim reporting, Journal of Accounting Research, 19 (Supplement), pp. 50-77.

[52] Leung, S., \& Horwitz, B. (2004). Director ownership and voluntary segment disclosure: Hong Kong evidence. Journal of International Financial Management and Accounting, 15(3), 235-260. https://doi.org/10.1111/j.1467-646X.2004.00109.x

[53] Liao, L., Luo, L., \& Tang, Q. (2015). Gender diversity, board independence, environmental committee and greenhouse gas disclosure. British Accounting Review, 47(4), 409-424. https://doi.org/10.1016/j.bar.2014.01.002

[54] Lin, S., Pope, P. and Young, S. (2003) Stock market reaction to the appointment of outside directors, Journal of Business, Finance and Accounting, 30: 351-82.

[55] Linsley, P. M., \& Shrives, P. J. (2005). Examining risk reporting in UK public companies. The Journal of Risk Finance, 6(4), 292-305. https://doi.org/10.1108/ 15265940510613633.

[56] Linsley, P. M., Shrives, P. J., \& Crumpton, M. (2006). Risk disclosure: An exploratory study of UK and Canadian banks. Journal of Banking Regulation, 7(3-4), 268-282. https://doi.org/10.1057/palgrave.jbr.2350032

[57] Linsley, P., \& Shrives, P. (2000). Risk management and reporting risk in the UK. The Journal of Risk, 3(1), 115-129. https://doi.org/10.21314/JOR.2000.034

[58] Madrigal, M.H., Guzmán, B.A. and Guzmán, C.A. (2015), "Determinants of corporate risk disclosure in large Spanish companies: a snapshot", Contaduría y Administración, Vol. 60, pp. 757-775. 
[59] Mallin, C. (2007). Corporate Governance (2 ${ }^{\text {nd }}$ Edition ed.).: Oxford. New York: University Press Oxford University Press Incorporation.

[60] Mannix, E., \& Neale, M. A. (2005). What differences make a difference? The promise and reality of diverse teams in organizations. Psychological Science in the Public Interest, Supplement. https://doi.org/10.1111/j.1529-1006.2005.00022.x

[61] Mautz, R.K., \&Sharaf, H.A. (1961). The philosophy of auditing. USA: American Accounting Association

[62] MCCG. (2017). Malaysian Code on Corporate Governance. Retrieved from https:// www.sc.com.my/wp-content/uploads/eng/html/cg/mccg2017.pdf

[63] Michelon, G., \& Parbonetti, A. (2012). The effect of corporate governance on sustainability disclosure. Journal of Management and Governance, 16(3), 477-509. https://doi.org/10.1007/s10997-010-9160-3

[64] Milne, M. J., \& Adler, R. W. (1999). Exploring the reliability of social and environmental disclosures content analysis. Accounting, Auditing \& Accountability Journal, 12(2), 237-256. https://doi.org/10.1108/09513579910270138

[65] Mohammadi, M. A. D. (2017). Corporate Governance and Financial Information Disclosure in a Developing Country. Universiti Teknologi Malaysia. Degree of Doctor Philosophy.

[66] Mohd Isa, R. (2006). Graphical Information in Corporate Annual Report: A Survey of Users and Prepares Perceptions. Journal of Financial Reporting \& Accounting, 4(1), 39-60.

[67] Morris, R. D. (1987). Signalling, Agency Theory and Accounting Policy Choice. Accounting and Business Research, 18(69), 47-56. https://doi.org/10.1080/ 00014788.1987.9729347

[68] Norwani, N. M., Mohamad, Z. Z., \& Chek, I. T. (2011). Corporate governance failure and its impact on financial reporting within selected companies, 2(21), 205-213.

[69] Ntim, C. G., Lindop, S., \& Thomas, D. A. (2013). Corporate governance and risk reporting in South Africa: A study of corporate risk disclosures in the pre- and post2007/2008 global financial crisis periods. International Review of Financial Analysis, 30, 363-383. https://doi.org/10.1016/j.irfa.2013.07.001

[70] Nuhu, M., \& Hussani, S. M. (2017). Empirical Study of the Relationship between Board of Director Mechanisms and Perceived Performance of Listed Firms in Nigeria, 3(2), 159-178.

[71] Oliveira, J., Rodrigues, L. L., \& Russell Craig. (2011). Risk-related Disclosures by Non-finance Companies: Portuguese Practices and Discloser Characteristics Riskrelated Disclosures by Non-finance Companies: Portuguese Practices and Discloser 
Characteristics Introduction. Managerial Auditing Journal, 26(9), 817-839.

[72] Orens, R., \& Lybaert, N. (2007). Does the financial analysts' usage of non-financial information influence the analysts' forecast accuracy? Some evidence from the Belgian sell-side financial analyst. International Journal of Accounting. https://doi. org/10.1016/j.intacc.2007.06.002

[73] Rahmat, M.M., \& Mohd Iskandar, T. (2004). Audit fee premiums from brand name, industry specialization and industry leadership: A study of the post Big 6 merger in Malaysia. Asian Review of Accounting, 12(2), 1-24.

[74] Rajab, B., \& Schachler, M. H. (2009). Corporate risk disclosure by UK firms: trends and determinants. World Review of Entrepreneurship, Management and Sustainable Development, 5(3), 224. https://doi.org/10.1504/WREMSD.2009.026801.

[75] Ray, D. M. (2005). Corporate boards and corporate democracy. Journal of Corporate Citizenship, 2005(20), 93-105. https://doi.org/10.9774/GLEAF.4700.2005.wi.00011

[76] Saggar, R., \& Singh, B. (2017). Corporate governance and risk reporting: Indian evidence. Managerial Auditing Journal, 32(4-5), 378-405. https://doi.org/10.1108/ MAJ-03-2016-1341

[77] Said Mokhtar, E., \& Mellett, H. (2013). Competition, corporate governance, ownership structure and risk reporting. Managerial Auditing Journal, 28(9), 838-865. https: //doi.org/10.1108/MAJ-11-2012-0776

[78] Sankaraguruswamy, S., \& Whisenant, S. (2003). Pricing Initial Audit Engagements: Empirical Evidence Following Public Disclosure of Audit Fees. SSRN Electronic Journal. https://doi.org/10.2139/ssrn.452680

[79] Sheila, N. H., Hafiz Majdi, A. R., Muhammad Akhyar, A., \& Ahamed Kameel, M. M. (2011). Corporate Governance and Risk Management Information Disclosure in Malaysian Listed Banks: Panel Data Analysis. International Review of Business Research Papers, 7(4), 159-176.

[80] Singhvi, S. S., \& Desai, H. B. (1971). An empirical analysis of the quality of corporate financial disclosure. The Accounting Review, 46(1), 129-138. Retrieved from http: //www.jstor.org/stable/243894

[81] Smith, M., \& Taffler, R. J. (2000). The chairman's statement - A content analysis of discretionary narrative disclosures. Accounting, Auditing \& Accountability Journal, 13(5), 624-647. https://doi.org/10.1108/09513570010353738

[82] Solomon, J. F., Solomon, A., Norton, S. D., Joseph, N. L., Boden, R., Hemmings, D., \& Whittington, G. (2000). a Conceptual Framework for Corporate Risk Disclosure Emerging From the Agenda for Corporate Governance Reform. British Accounting Review, 32(April 1999), 447-478. https://doi.org/10.1006 
[83] Solomon, J.F., Solomon, A., Norton, S.D. and Joseph, N.L. (2011), "Private climate change reporting: an emerging discourse of risk and opportunity?", Accounting, Auditing \& Accountability Journal, Vol. 24 No. 8, pp. 1119-1148.

[84] Spence, M. (1973). Job market signaling. The Quarterly Journal of Economics, 87(3), 355. https://doi.org/10.2307/1882010

[85] Spence, M. (2002). Signaling in retrospect and the informational structure of markets. American Economic Review. https://doi.org/10.1257/00028280260136200

[86] Stanley, J. D., \& Todd DeZoort, F. (2007). Audit firm tenure and financial restatements: An analysis of industry specialization and fee effects. Journal of Accounting and Public Policy, 26(2), 131-159. https://doi.org/10.1016/j.jaccpubpol.2007.02.003

[87] Susela, S. D. (1999). "Interests" and accounting standard setting in Malaysia. Accounting, Auditing \& Accountability Journal, 12(3), 358-387. https://doi.org/10. $1108 / 09513579910277410$

[88] Tang, Q., Chen, H., \& Lin, Z. (2016). How to measure country-level financial reporting quality? Journal of Financial Reporting and Accounting, 14(2), 230-265. https://doi. org/10.1108/JFRA-09-2014-0073

[89] Tepalagul, N., \& Lin, L. (2015). Auditor Independence and Audit Quality: A Literature Review. Journal of Accounting, Auditing \& Finance, 30(1), 101-121. https://doi.org/10. 1177/0148558X14544505

[90] Wahab, E. A. A., Gist, W. E., \& Majid, W. Z. N. A. (2014). Characteristics of nonaudit services and financial restatements in Malaysia. Journal of Contemporary Accounting and Economics, 10(3), 225-247. https://doi.org/10.1016/j.jcae.2014.10.001

[91] Wallace, R. S. O., and Naser, K. (1995). Firm-specific determinants of the comprehensiveness of mandatory disclosure in the corporate annual reports of firms listed on the Stock Exchange of Hong Kong. Journal of Accounting and Public Policy. 14(4), 311-368

[92] Wallace, R. S. O., Naser, K., and Mora, A. (1994). The relationship between the comprehensiveness of corporate annual reports and firm characteristics in Spain. Accounting and Business Research. 25(97), 41-53.

[93] Watson, A., Shrives, P., \& Marston, C. (2002). Voluntary disclosure of accounting ratios in the UK. British Accounting Review. https://doi.org/10.1006/bare.2002.0213

[94] Weisbach, M. S., \& Hermalin, B. E. (2000). Boards of Directors as an Endogenously Determined Institution: A Survey of the Economic Literature. SSRN Electronic Journal. https://doi.org/10.2139/ssrn.233111

[95] Williams, D. R., Duncan, W. J., Ginter, P. M., \& Shewchuk, R. M. (2006). Do governance, equity characteristics, and venture capital nvolvement affect long-term wealth 
creation in U.S. health care and biotechnology IPOs? J Health Care Finance, 33(1), 54-71. Retrieved from http://www.ncbi.nlm.nih.gov/pubmed/21110493

[96] Xie, B., Davidson, W. N., \& DaDalt, P. J. (2003). Earnings management and corporate governance: the role of the board and the audit committee. Journal of Corporate Finance, 9(3), 295-316. https://doi.org/10.1016/S0929-1199(02)00006-8

[97] Zadeh, F. O. (2015). Corporate governance, risk disclosure and cost of equity capital in the malaysian public listed firm.

[98] Zadeh, F. O., Zaleha, S., Rasid, A., \& Basiruddin, R. (2016). Risk Disclosure Practices among Malaysian Listed Firms. International Journal of Economics and Financial Issues, 6(3), 4138.

[99] Zaluki, N. A. A., \& Wan Hussin, W. N. (2009). Corporate Boards, Audit Committees and Quality of Financial Disclosure in IPOs. SSRN eLibr. 